\title{
Comparative Study of Weekly and Three Weekly Chemoradiation Regimen in Advanced Head and Neck Cancer at Silchar Medical College
}

\author{
Dr. Smrity R. B. Dutta ${ }^{1}$, Dr. Yousuf F. Choudhury ${ }^{2}$ \\ ${ }^{1}$ Associate Professor, Department of Otolaryngology, Head and Neck Surgery \\ ${ }^{2}$ Post Graduate Trainee, Department of Otolaryngology, Head and Neck Surgery
}

\begin{abstract}
Majority of head and neck cancer cases present in an advancedstage and at sites where resection is not easy or it is impossible. For such cases, definitive chemoradiation is the solution. Cisplatin-basedchemoradiationis the most common modality in chemoradiation in head and neck cancer world. There is a debate regarding the schedule of regimen whether weekly or three weekly regimens. With this in mind, we aim to compare the response, compliance, and toxicities of weekly low-dose cisplatin regimen and three weekly high-dose cisplatin regimen in our study. Materials \& Methods: 41 patients were eligible for the prospective study in the department of ENT, Silchar Medical College. 24 in arm A (weekly based regimen) and 17 in arm B (three weekly based regimen) were studied for response to chemoradiation, compliance of treatment and their toxicities. The patients were divided into two arms; Arm A i.e. Cisplatin 30mg/kg body weight in one day given weekly for 6 cycles and Arm B i.e. Cisplatin 100mg/kg body weight in two days given three weekly for 3 cycles. Radiations were deliveredin a fraction of 2 Gy per day for 5 days per week for 6-7 weeks amounting to a total range of 60-70 Gy in both arms. Results \& Observations: $70.73 \%$ of total patients showed a complete response. $75 \%$ of weekly regimen and $64.7 \%$ of three weekly regimens showed a complete response. $79.2 \%$, $64.7 \%$ of cases of weekly and three weekly regimens respectively completed their treatment. Mucositis was the most common toxicity in both arms involving all the patients. Grade III toxicities are more in arm $B(64.7 \%)$ than in arm $A(41.6 \%)$. Anemia, leucopenia, and vomiting are more in arm $B$ than in arm A. Leucopenia in arm B is more esp. grade III and it's statistically significant. Conclusion: Toxicities are more in three weekly regimens than weekly regimen. Response and compliance are more in weekly regimen than three weekly regimens. Hence it can be concluded that weekly low-dose cisplatin regimen is superior to three weekly high-dose cisplatin regimen.
\end{abstract}

Keywords: Chemotherapy in Head and Neck cancer, Cisplatin, weekly regimen, three weekly regimens, chemotherapy toxicity

\section{Introduction}

With the advent of chemotherapy, a new regimen of thecombined modality of chemotherapy and radiation has arisen in the last two decades as a definitive treatment for unresectable or difficult to resect head and neck cancer cases. It certainly has improved the survival rates but with thehigh rate of complications which is the limiting factor for most patients. Cisplatin-based chemotherapy or chemoradiation regimen is the most commonly used in head and neck cancer but there is adebate about the schedule of treatment. A weekly regimen of low dose and three weekly regimens of high-dose are the two most sought-after regimen in practice in head and neck cancer. In our endeavor to contribute to the ongoing research, we have studied the effectiveness, complications, and compliance of weekly and three weekly cisplatin-basedchemoradiation regimen in our head and neck cancer patients of the department.

\section{Materials and Methods}

This is arandomizedprospective study conducted at the Department of ENT, Silchar Medical College between the period of August 2015 to July 2017. Forty-one eligible patients with locally advanced carcinoma of oropharynx, hypopharynx, and larynx were taken into the study. The study was approved by theinstitutional ethical committee.

Inclusion criteria: Locally advanced stage (TNM stage IIIIV excluding metastasis ), histologically proven as squamous cell carcinoma, Karnofskyscores more than 70 and normal hematological and biochemical parameters.

Exclusion criteria: Prior history of chemotherapy, radiotherapy, metastasis.

The patients were divided into two arms; Arm A i.e. Cisplatin $30 \mathrm{mg} / \mathrm{kg}$ body weight in one daygiven weekly for 6 cycles and Arm B i.e. Cisplatin $100 \mathrm{mg} / \mathrm{kg}$ body weight in two days given three weekly for 3 cycles. Radiations are given in fractions of 2 Gy per day for 5 days weekly for 6-7 weeks amounting to the total range of 60-70Gy.Clinical examination, endoscopy, and CT scan are done after one month to evaluate the response of chemoradiation. Toxicities are evaluated using RTOG scale.

Patients were followed up monthly.

Out of 41 patients, 24 patients were in arm A and 17 in arm B.

\section{Results \& Observations}

From the table no. 1, it was observed that the median age is 60 years, prevalence of male gender was much higher, most common site is oropharynx (39\%), most common histological grading is moderately differentiated (44\%) and most common stage is stage III $(31 \%)$ 


\section{International Journal of Science and Research (IJSR) \\ ISSN (Online): 2319-7064}

Index Copernicus Value (2016): 79.57 | Impact Factor (2015): 6.391

Table 1: Showing Patient Characteristics in the Study

\begin{tabular}{|l|c|c|c|}
\hline & Total & Arm A & Arm B \\
\hline Age (Median) & 60 & 58 & 60 \\
\hline SEX & & & \\
\hline Male & 34 & 19 & 15 \\
\hline Female & 7 & 5 & 2 \\
\hline Male: Female & $4.85: 1$ & $3.8: 1$ & $7.5: 1$ \\
\hline SITE & & & \\
\hline Oropharynx & $16(39 \%)$ & $10(42 \%)$ & $6(35 \%)$ \\
\hline Hypopharynx & $13(32 \%)$ & $6(25 \%)$ & $7(41 \%)$ \\
\hline Larynx & $12(29 \%)$ & $8(33 \%)$ & $4(24 \%)$ \\
\hline Histological Grading & & & \\
\hline Well differentiated & $9(22 \%)$ & $6(25 \%)$ & $3(18 \%)$ \\
\hline Moderately differentiated & $18(44 \%)$ & $14(58 \%)$ & $8(47 \%)$ \\
\hline Poorly differentiated & $14(34 \%)$ & $4(17 \%)$ & $6(35 \%)$ \\
\hline STAGING & & & \\
\hline III & $31(76 \%)$ & $19(79 \%)$ & $12(71 \%)$ \\
\hline IV & $10(24 \%)$ & $5(21 \%)$ & $5(29 \%)$ \\
\hline
\end{tabular}

\section{Response assessment}

Out of the 41 patients, $70.73 \%$ patients showed complete response and $29.26 \%$ partial response. $75 \%$ in weekly regimen showed acomplete response, $64.7 \%$ in three weekly regimens showed acomplete response. It was statistically not significant. ( $\left.\mathrm{p}=0.475, \mathrm{X}^{2}=0.509\right)$.

Table 2: Showing Response Rate of Both Arms

\begin{tabular}{|c|c|c|c|}
\hline Response & Total & ARM A & ARM B \\
\hline Total Response & 29 & $18(75 \%)$ & $11(64.7 \%)$ \\
\hline Partial Response & 12 & $6(25 \%)$ & $6(35.3 \%)$ \\
\hline
\end{tabular}

\section{Toxicities assessment}

All the patients receiving either regimen suffered from chemotherapeutic toxicities more or less. Using the RTOG scale for acute toxicities, $64.7 \%$ cases of three weekly regimens showed grade III toxicity while only $41.6 \%$ of weekly regimen showed grade III toxicity.

Anemia, Leucopenia, and Vomiting are more in arm B than arm A. Statistically onlythe incidence of leucopenia is significantly more in arm B than A $\left(p=0.011, X^{2}=6.46\right)$. Grade III leucopenia, grade II vomiting was significantly more in arm B. The incidence of Dermatitis and Dysphagia are almost equal in both arms with not much difference in grading also.

Table 3: Showing Toxicities of Both Arms

\begin{tabular}{|l|l|l|l|l|l|l|l|l|}
\hline \multirow{2}{*}{ Toxicities } & GRADE I & \multicolumn{2}{l|}{ GRADE II } & \multicolumn{2}{l|}{ GRADE II } & \multicolumn{2}{l|}{ GRADE IV } \\
\cline { 2 - 9 } & Arm A & Arm B & Arm A & Arm B & Arm A & Arm B & Arm A & Arm B \\
\hline Dermatitis & $8(33 \%)$ & $6(35 \%)$ & $2(8 \%)$ & $1(6 \%)$ & 0 & 0 & 0 & 0 \\
\hline Mucositis & $11(46 \%)$ & $7(41 \%)$ & $9(37 \%)$ & $8(47 \%)$ & $4(17 \%)$ & $2(12 \%)$ & 0 & 0 \\
\hline Dysphagia & $6(25 \%)$ & $4(23 \%)$ & $4(16.67 \%)$ & $4(24 \%)$ & $3(12 \%)$ & $2(12 \%)$ & 0 & 0 \\
\hline Vomiting & $8(33 \%)$ & $6(35 \%)$ & $4(21 \%)$ & $7(41 \%)$ & $1(4 \%))$ & $3(18 \%)$ & 0 & 0 \\
\hline Anemia & $8(33 \%)$ & $5(29 \%)$ & $4(17 \%)$ & $6(35 \%)$ & $2(8 \%)$ & $2(12 \%)$ & 0 & 0 \\
\hline Leucopenia & $4(17 \%)$ & $6(35 \%)$ & $2(8 \%)$ & $3(18 \%)$ & 0 & $2(12 \%)$ & 0 & 0 \\
\hline
\end{tabular}

Compliance assessment

19 out of 24 cases $(79.2 \%)$ of arm A completed their weekly 6 cycles while 11 out of 17 cases $(64.7 \%)$ of arm B completed their three weekly 3 cycles. Though in terms of percentage it seems compliance is more in arm A, statistically it is not significant. It has been observed that there were interruptions in both arms but were not significant. Two patients $(8 \%)$ refused completion of radiation in arm A and one patient in arm B (6\%). Interruptions in radiationwere not analyzed properly.

\section{Discussion}

There is no definite protocol till date regarding the definitive chemoradiation treatment of locally advanced squamous cell carcinoma of head and neck region. Several trials with several chemotherapeutic agents and radiation with different schedules have been going on in the head and neck cancer world amongst whom monotherapy cisplatin $100 \mathrm{mg} / \mathrm{m}^{2}$ three weekly regimens wasthe most frequent and accepted chemotherapy regimen in the world. It is being considered as the standard. However, with good response rate, they come with thegood amount of toxicities esp. of higher grades. In the pursuit of fewer toxicities with good response rate, lowdose cisplatin given weekly for 6 cycles regimen has been proposed and tried.

In our study, we found that the complete response rates of the tumor in weekly and three weekly were $75 \%$ and $64.7 \%$ respectively. In Rawatet al. study, there was not much difference between the weekly and three weekly chemotherapy regimen. In Tapan Kumar Sahoo et al. study, they found $73.33 \%$ and $85.71 \%$ in weekly and three weekly cisplatin chemotherapy regimen respectively which shows abetter response in three weekly regimens. Also in Mitra et al. study, they found thethree weekly better than weekly chemotherapy in terms of response. According to Homma et al. study, there were $98.1 \%$ complete response on weekly Cisplatin $40 \mathrm{mg} / \mathrm{kg}$ body weight in stage II-IV HNSCC.

It was observed that mucositis was the most common toxic symptom of cisplatin-basedchemoradiation whether it is weekly or three weekly regimen. In our studies, grade III mucositis was $17 \%$ and $12 \%$ in weekly and three weekly regimens respectively. This was supported by the Geeta $\mathbf{S N}$ study et al.But in studies,Tapan Kumar Sahoo et al., Mitra et al.,Azony et al., grade III mucositisis more in three weeklythan weekly chemotherapy regimen.

Vomiting in our studies was $54.16 \%$ in theweekly regimen and $76.47 \%$ in three weekly regimens respectively. The difference in this study was statistically significant. ( $\left.\mathrm{p}=0.005, \mathrm{X}^{2}=7.62\right)$. Our study corroborated with the studies of Rawat et al.and Azony et al. where the incidence was more in three weekly. Grade III vomiting is more in our study.

Hematological toxicity likeanemia and leucopenia are the most important toxicity of chemotherapeutic agents. They are the limiting factors for stoppage of treatment. In our

\section{Volume 6 Issue 12, December 2017}




\section{International Journal of Science and Research (IJSR) \\ ISSN (Online): 2319-7064 \\ Index Copernicus Value (2016): 79.57 | Impact Factor (2015): 6.391}

study, both anemia and leucopenia were much higher in three weekly cisplatin regimenthan weekly regimen. We found $35 \%$ and $65 \%$ leucopenia in weekly and three weekly respectively with theincidence of grade III and II leucopenia more in three weeklyregimens. $76 \%$ and $58 \%$ of total cases of three weekly and weekly cisplatin regimen suffered from anemia respectively. Increase in Leucopenia was statistically significant in our study but not anemia. We got grade III leucopenia only in three weekly regimens i.e., $12 \%$. In regards to anemia, according to Rawat $\boldsymbol{S}$ et al., $55.2 \%$ cases in three weekly arm and $26.7 \%$ cases in weekly arm were with neutropenia. According to Mitra D et al., $33 \%$ of cases in theweekly arm and $43 \%$ cases in three weekly arms were with grade III neutropenia. According to Tapan Kumar Sahoo et al., they found $6.67 \%$ grade III anemia in weekly chemotherapy regimen, which is similar to our finding i.e. $8 \%$.

When theoverall analysis was done, it was observed that grade III toxicity was higher in three weekly regimens than weekly regimen i.e., $66 \%$ vs $41 \%$.

All the patients were alive except for one patient withstage IV oropharyngeal cancer of arm A (weekly regimen) who after completing chemoradiationdied suddenly.

Table 4: Showing Comparison Of Different Studies

\begin{tabular}{|c|c|c|c|c|c|c|c|c|c|}
\hline $\begin{array}{c}\text { Serial } \\
\text { no. }\end{array}$ & Study & $\begin{array}{c}\text { No. of } \\
\text { cases }\end{array}$ & $\begin{array}{l}\text { weekly \& } 3 \\
\text { weekly dose }\end{array}$ & $\begin{array}{l}\text { treatment } \\
\text { response }\end{array}$ & $\begin{array}{l}\text { treatment } \\
\text { compliance }\end{array}$ & anemia & leukopenia & mucositis & vomiting \\
\hline 1 & Our study & 41 & 30vs100 & $\begin{array}{c}66 \% \text { in } \\
\text { weekly vs } \\
53 \% \text { three } \\
\text { weekly }\end{array}$ & $\begin{array}{c}\uparrow \text { in } \\
\text { weekly }(71 \% \\
\text { vs } 47 \%)\end{array}$ & $\begin{array}{c}\uparrow \text { in } 3 \text { weekly } \\
(88 \% \text { vs } 83 \%) \\
\text { Gr. II, III more } \\
\text { in } 3 \text { weekly } \\
\end{array}$ & $\begin{array}{l}\uparrow \text { in } 3 \text { weekly } \\
(65 \% \text { vs } 25 \%) \\
\text { gr II, III more } \\
\text { in 3weekly }\end{array}$ & $\begin{array}{l}\text { almost similar } \\
\text { in both regimen }\end{array}$ & $\begin{array}{c}\uparrow \text { in } 3 \text { weekly } \\
(94.1 \text { vs } 54.1 \%)\end{array}$ \\
\hline 2 & $\begin{array}{c}\text { Tapan Kumar } \\
\text { Sahooet al }\end{array}$ & 30 & 30vs100 & $\begin{array}{c}73 \% \text { in } \\
\text { weekly vs } \\
85.71 \% \\
\text { three } \\
\text { weekly }\end{array}$ & $\begin{array}{c}\uparrow \text { in } \\
\text { weekly }(67 \% \\
\text { vs } 47 \%)\end{array}$ & $\begin{array}{c}\uparrow \text { in weekly } \\
(73 \% \text { vs67\%) } \\
\text { Gr. II more in } \\
\text { weekly }\end{array}$ & $\begin{array}{l}\text { 个 in weekly } \\
(87 \% \text { vs73\%) }\end{array}$ & $\begin{array}{l}\text { All the patients } \\
\text { were affected. } \\
\text { Gr. III \& IV } \\
\text { more in } 3 \\
\text { weekly }\end{array}$ & $\begin{array}{l}\uparrow \text { in } 3 \text { weekly } \\
(94.1 \text { vs } 54.1 \%)\end{array}$ \\
\hline 3 & Geeta $S N$ et al & 83 & $40 \mathrm{vs} 100$ & - & $\uparrow$ in 3 weekly & $\uparrow$ in weekly & $\uparrow$ in weekly & $\uparrow$ in weekly & - \\
\hline 4 & Azony et al & 40 & $30 \mathrm{vs} 100$ & - & - & - & $\uparrow$ in 3 weekly & similar & $\uparrow$ in 3 weekly \\
\hline 5 & Mitra et al & 90 & $30 \mathrm{vs} 100$ & $\begin{array}{c}76 \% \text { in } 3 \\
\text { weekly vs } \\
67 \% \text { in } \\
\text { weekly }\end{array}$ & - & $\uparrow$ in 3 weekly & $\uparrow$ in 3 weekly & $\begin{array}{l}\text { Similar but } \\
\text { grade III } \\
\text { mucositis } \uparrow \text { in } \\
\text { weekly }\end{array}$ & $\uparrow$ in weekly \\
\hline
\end{tabular}

\section{Conclusion}

From our study, it can be concluded that response rateis better in weekly regimen than three weekly regimens but this cannot be a decisive factor for preference to weekly regimen till the overall survival of cases of both regimensisn'tanalyzed. On the other hand looking at the toxicities profile and compliance, weekly regimen seems superior to three weekly regimens. Further studies by increasing the number of cases, and prolong follow-up will certainly establish which regimen is exactly superior.

\section{References}

[1] Cox JD, Stetz J, Pajak TF. Toxicity criteria of the Radiation Therapy OncologyGroup (RTOG) and the European Organization for Research and Treatment ofCancer (EORTC). Int $\mathrm{J}$ RadiatOncolBiol Phys. 1995;31(5):1341-46.

[2] Rawat S, Srivastava H, Ahlawat P, Pal M, Gupta G, Chauhan D, et al. Weeklyversus three-Weekly Cisplatinbased Concurrent Chemoradiotherapy asdefinitive treatment in Head and Neck Cancer - Where do we stand? Gulf journalof oncology. 2016;21:6-11

[3] Tapan Kumar Sahoo,Dipti Rani Samanta, SurendraNathSenapati, KarishmaParida A Comparative Study on Weekly Versus Three Weekly Cisplatinum Based Chemoradiation in Locally Advanced Head and Neck Cancers J ClinDiagn Res. 2017 Jan;11(1): XC07XC11. doi: 10.7860/JCDR/2017/24765.9293. Epub 2017 Jan 1 .
[4] Mitra D, Choudhury K, Rashid MA. Concurrent chemotherapy in advancedhead and neck carcinoma- A prospective randomized trial. Bangladesh J Otorhinolaryngol. 2011;17(2):88-95

[5] Homma A, Inamura N, Oridate N, Suzuki S, Hatakeyama $\mathrm{H}$, Mizumachi T, et al.Concomitant weekly cisplatin and radiotherapy for head and neck cancer. Jpn JClinOncol. 2011;41:980-86.

[6] Geeta SN, Padmanabhan TK, Samuel J, Pavithran K, Kuriakose MA. Comparisonof acute toxicities of two chemotherapy schedules for head and neck cancers. J Cancer Res Ther. 2006;2:100-04.

[7] Homma A, Inamura N, Oridate N, Suzuki S, Hatakeyama $\mathrm{H}$, Mizumachi $\mathrm{T}$, et al.Concomitant weekly cisplatin and radiotherapy for head and neck cancer. Jpn JClinOncol. 2011;41:980-86.

[8] Azony AE, Sarhan AM, Hamouda WE, et al. Treatment outcome of concurrentchemoradiotherapy in locally advanced squamous cell carcinoma of the headand neck. ZUMJ. 2012;18(5). 